\title{
Improving the sustainability of tilapia cage farming in Brazil: An emergy approach
}

\author{
Luiz Henrique Castro David ${ }^{\text {a, }}$, Sara Mello Pinho a , Fabiana Garcia a, b \\ a Centro de Aquicultura da Unesp (CAUNESP) - Universidade Estadual Paulista 'Júlio de Mesquita Filho', Jaboticabal, São Paulo, Brazil \\ ${ }^{\mathrm{b}}$ Instituto de Pesca, APTA/SAA, São José do Rio Preto, São Paulo, Brazil
}

\section{A R T I C L E I N F O}

\section{Article history:}

Received 12 April 2018

Received in revised form

19 June 2018

Accepted 12 August 2018

Available online 14 August 2018

\section{Keywords:}

Emergy

Aquaculture

Periphyton

Density stocking

Commercial feed

\begin{abstract}
A B S T R A C T
The accelerated and disorderly expansion of aquaculture can lead to economic, social, and environmental problems. In this sense, it is necessary to prioritize the adoption of practices that aim for sustainable production. The aims of the present study were to identify the contributions from nature and economy in the system of tilapia cage farming. In addition, emergy accounting was utilized to evaluate whether the use of periphyton as a complementary food and the reduction of storage density improve the sustainability of this production system. Three different production managements were evaluated and compared: using traditional stocking density adopted by farmers $\left(80 \mathrm{~kg} / \mathrm{m}^{3}\right)$ with $100 \%$ of the daily recommended feed and without substrates for periphyton (TRAD); traditional stocking density ( $80 \mathrm{~kg} /$ $\mathrm{m}^{3}$ ) with $50 \%$ of the daily recommended feed and with substrates for periphyton (TDS); lower density $\left(40 \mathrm{~kg} / \mathrm{m}^{3}\right)$ with $50 \%$ of the daily recommended feed and with substrates for periphyton (LDS). We calculated using emergy accounting the transformity (Tr), renewability (\%R), emergy yield ratio (EYR), emergy investment ratio (EIR), emergy loading ratio (ELR), emergy exchange ratio (EER), and emergy sustainability index (ESI) of the distinct production managements. The results showed that tilapia cage farming is highly dependent on resources from economy, and feed is mainly responsible for this. Thus, the decrease in stocking density and feed rate, combined with the use of periphyton, improved all emergy indices evaluated. This occurred because there was a decrease in the use of resources from economy and increase in the use of renewable natural resources. The study shows through the emergy accounting that the use of periphyton to feed cultured fish combined with a reduction in artificial feed use and a decrease in the stocking density should be encouraged to promote the sustainability on tilapia cage farming.
\end{abstract}

Published by Elsevier Ltd.

\section{Introduction}

Population growth and the consequent increased demand for high quality food have contributed to the global expansion of aquaculture in recent years (FAO, 2016). However, the disordered development of this activity may have negative effects on the environment (Bronnmann and Asche, 2017). The intensification of systems based on the high use of non-renewable natural resources, combined with the non-adoption of best management practices to achieve high yields, can adversely affect the environmental balance and compromise the future growth of aquaculture (Boyd, 2003;

\footnotetext{
* Corresponding author. Centro de Aquicultura da Unesp - CAUNESP, Via de Acesso Prof. Paulo Donato Castellane, s/n, 14884-900, Jaboticabal, SP, Brazil.

E-mail addresses: luiz.h@outlook.com (L.H.C. David), sara.pinhoo@hotmail.com (S.M. Pinho), fgarcia@apta.sp.gov.br (F. Garcia).
}

Valenti et al., 2011).

In Brazil, fish farming is represented mainly by tilapia (Oreochromis niloticus) and tambaqui (Colossoma macropomum) in semiintensive systems (IBGE, 2015). However, intensive production of tilapia in cages prevails in São Paulo State, which traditionally employs high stocking densities $\left(>80 \mathrm{~kg} / \mathrm{m}^{3}\right)$ and large amounts of feed to achieve high productivity in small cages (Marengoni, 2006). Sometimes this type of farming has caused undesirable consequences, such as accumulation of nutrients in the sediment (Mallasen et al., 2012), the high cost of inputs for the manufacturing of feed (Ayroza et al., 2011; Garcia et al., 2017), outbreaks of diseases and the consequent use of therapeutic products which can result in residue accumulation in the environment and in the fish (Garcia et al., 2013; Monteiro et al., 2016; Maciel et al., 2017).

Methods for sustainability assessment, such as emergy accounting, point out that sustainable production systems are those 
that emit low environmental pollutants, use local renewable resources as the main sources of energy, and have low dependence on non-renewable external resources (Brown and Ulgiati, 1997). In this way, it becomes necessary to guide aquaculture farmers to adopt practices that attend to this concept of sustainability to maximize productive efficiency, but also to reduce losses, costs, and negative environmental impacts, increasing the possibility of success over time (Wilfart et al., 2013). One strategy for this is to reduce dependence on feed (Garcia et al., 2014), for example, by reducing the stocking density (Garcia et al., 2013) and using periphyton as a natural food (Garcia et al., 2016). The periphyton community develops naturally on submerged substrates like rocks, woods, plants and sediments. It is comprised of green algae, diatoms, bacteria, fungi, protozoans, zooplankton and smaller invertebrates (Azim and Asaeda, 2005).

The use of periphyton to feed cultured fish combined with a decrease in the stocking density improves the growth performance, decreases the time of rearing, and reduces the feed conversion rate in tilapia cage farming (Garcia et al., 2016). This improvement in performance can also provide satisfactory economic results, such as annual yields of up to $57 \%$ and $87 \%$ higher profitability than the traditional production system (Garcia et al., 2017). However, technical and economic results are not enough to ensure the sustainability of the system because these evaluations do not consider the inputs of environmental resources by the productive activity (Valenti et al., 2011). The adoption of methods that measure sustainability can be a solution to this problem.

Emergy accounting is one such method able to consider environmental and economic aspects of the production systems (Odum, 1996). This method considers all inputs and outputs of natural, human labor and economic resources in the system, this allows to compare and calculate the part of each kind of energy flow (joules of solar emergy [seJ]) in the system, independent of the strictly monetary perception (Odum, 1996; Brown and Ulgiati, 1997; Copeland et al., 2010). It can be used in the decisions and definition of public policies for the use of natural resources, as reported by Lomas et al. (2008) in the evaluation of preservation policies in Spain, and by Pulselli (2010) in the monitoring of resource use by the communities of Abruzzo, Italy.

Thus, we formulate the hypothesis that reduced densities and the use of periphyton as a natural food can reduce the use of nonrenewable resources and promote the sustainability of traditional tilapia cage farming. The aim of the present study is to evaluate by emergy accounting if these strategies improve the sustainability of tilapia cage farming. In addition, we identify the contributions from the nature and the economy of this production system.

\section{Material and methods}

\subsection{Systems description}

An analysis was conducted on the use of different densities of stocking and periphyton as complementary food (by the introduction of bamboo substrates in the cages and colonization of these microorganisms at the added surface) in an experiment carried out in a tilapia cage farm at the Nova Avanhandava Reservoir, Tietê

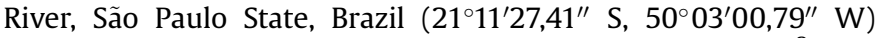
which produces $40 \mathrm{t}$ per month. The experimental cages $\left(6 \mathrm{~m}^{3}\right.$ each one) were installed inside the farm to evaluate different production managements, with three replicates (cages) per treatment (Garcia et al., 2016): using traditional stocking density adopted by Brazilian fish farmers $\left(80 \mathrm{~kg} / \mathrm{m}^{3}\right)$ with $100 \%$ of the daily recommended feed and without substrates for periphyton (TRAD); traditional stocking density $\left(80 \mathrm{~kg} / \mathrm{m}^{3}\right)$ with $50 \%$ of the daily recommended feed and with substrates for periphyton (TDS); lower density $\left(40 \mathrm{~kg} / \mathrm{m}^{3}\right)$ with $50 \%$ of the daily recommended feed and with substrates for periphyton (LDS). The treatment that received $100 \%$ of daily ration (TRAD) was fed twice a day (8:00 h and 16:00 h), and the treatments that received $50 \%$ of daily ration (TDS and LDS) was fed only in the afternoon $(16: 00 \mathrm{~h})$. The aim of this management was to stimulate fish to eat periphyton during day time. The experiment details are described in Garcia et al. (2016). The production data used were obtained from Garcia et al. (2016) and the economics data from Garcia et al. (2017) (Table 1), all these data were submitted to the appropriate statistical analysis (two-way ANOVA) by these authors and represent real situations of commercial production.

\subsection{Emergy accounting}

Emergy accounting was used to evaluate the sustainability of the three production managements in tilapia cage farming: using traditional stocking density adopted by Brazilian fish farmers $\left(80 \mathrm{~kg} / \mathrm{m}^{3}\right)$ with $100 \%$ of the daily recommended feed and without substrates for periphyton (TRAD); traditional stocking density $\left(80 \mathrm{~kg} / \mathrm{m}^{3}\right)$ with $50 \%$ of the daily recommended feed and with substrates for periphyton (TDS); lower density $\left(40 \mathrm{~kg} / \mathrm{m}^{3}\right.$ ) with $50 \%$ of the daily recommended feed and with substrates for periphyton (LDS). From the knowledge of the energy flow of the production system, the diagram was built based on energy systems symbols (Odum, 1996), which presents the energy transformation ways within the systems, from the primary sources and inputs to the final product (Fig. 1).

Based on the understanding of all energy sources and resources used in the evaluated management, the inputs and outputs of resources were categorized into: renewable resources (R), economic resources $(F)$ as inputs, and yield $(Y)$ as output. The energy inputs were quantified in units of mass $(\mathrm{kg})$ or energy (joules) to be compatible with the units used in the global productivity factor or transformity of each item. However, some items could not be accounted for in these units and they were valued in monetary unit and converted into emergy equivalents by multiplying the money flow (US\$) with the ratio obtained from the national census values (ratio = gross national product dollars/emergy from the country in the reference year). The equations for the energy calculations of each input are described in Appendix A. The conversion calculations are described in Appendices B, C, and D.

The inputs of resources had their UEVs (Unit Emergy Value) determined according to the data available in the literature. All the UEVs found are on a baseline of $1.20 \mathrm{E}+25 \mathrm{sej} / \mathrm{year}$ (Campbell, 2016). When we verified divergences in the baseline, they were converted to obtain updated and comparable values (Campbell et al., 2005; Brown et al., 2016; Brown and Ulgiati, 2016).

For the emergy calculations, the area of one cage $\left(4 \mathrm{~m}^{2}\right.$ in this

Table 1

Technical and economic characteristics of systems using periphyton as supplementary feed for tilapia in cages at different stocking densities.

\begin{tabular}{|c|c|c|c|c|}
\hline Item & Unit & TRAD & TDS & LDS \\
\hline Stocking density & $\mathrm{kg} / \mathrm{m}^{3}$ & 80.00 & 80.00 & 40.00 \\
\hline Feed & $\%$ & 100.00 & 50.00 & 50.00 \\
\hline Substrates & - & No & Yes & Yes \\
\hline Total production & $\mathrm{kg} /$ cage & 411.79 & 417.84 & 214.54 \\
\hline Weight gain & kg/fish & 0.72 & 0.65 & 0.71 \\
\hline Feed conversion ratio & - & 1.84 & 1.29 & 1.06 \\
\hline Productive cycles & cycles/year & 1.80 & 1.49 & 1.45 \\
\hline Human labor ${ }^{a}$ & hours/cage & 24.00 & 26.40 & 23.40 \\
\hline Cage capacity & $\mathrm{m}^{3}$ & 6.00 & 6.00 & 6.00 \\
\hline
\end{tabular}

${ }^{\text {a }}$ Labor (total hours spent by cage) for each activity to rear tilapia in cages with or without use of substrates. 


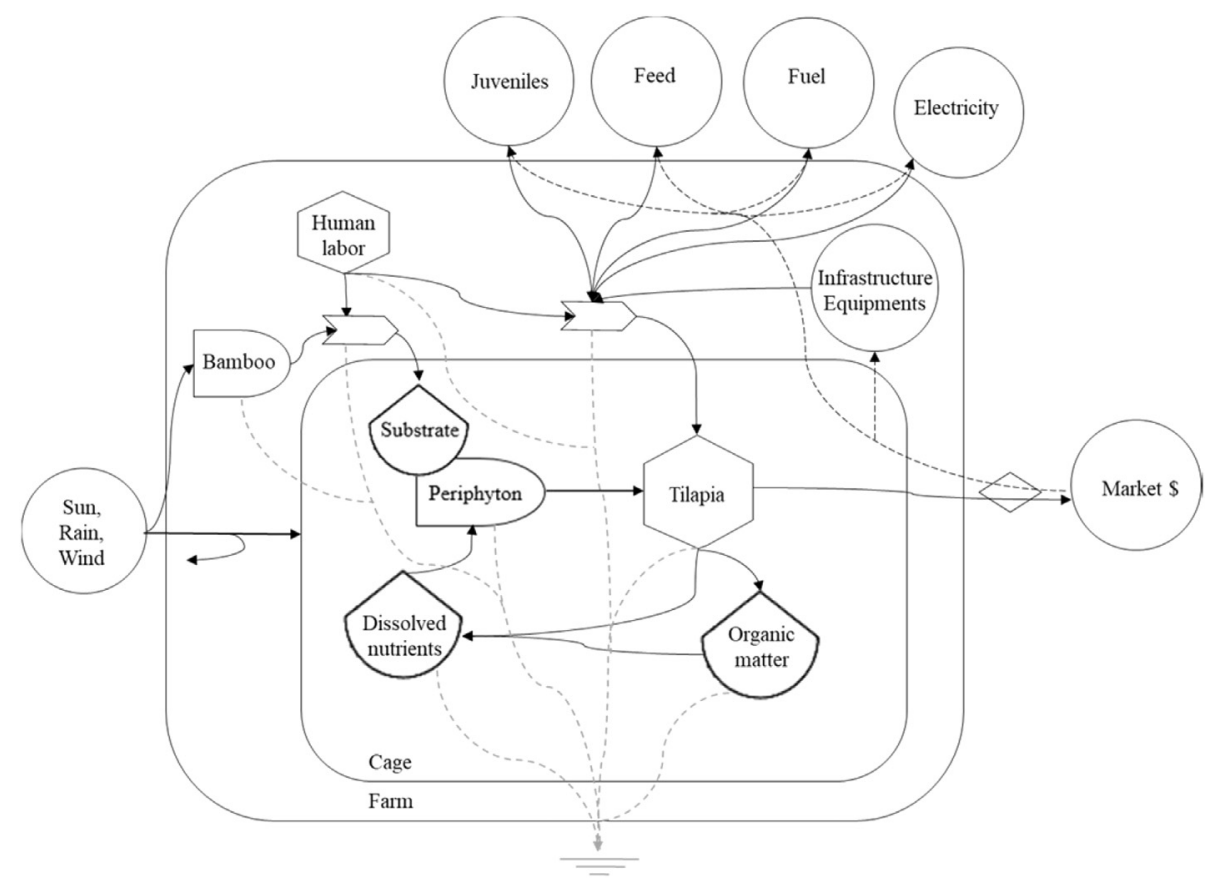

Fig. 1. The energy system diagram of tilapia cage farming with bamboo substrates for periphyton.

study) and the dilution area of the organic load ratio were considered, as established by Brazilian Federal Legislation in 1:8 (BRASIL, 2004). In addition, the legislation of São Paulo State was respected, which establishes a maximum limit of $1 \%$ of the surface area of closed or semi-open reservoirs to be occupied by aquaculture parks in state public waters (SÃO PAULO, 2016). Following this, the area of the natural renewable resources supply was defined as $3200 \mathrm{~m}^{2}$ per cage.

\subsubsection{Emergy indices}

The emergy indices show various aspects of ecosystem, such as resource use intensity, process efficiency, economic-environment interactions, and system's sustainability based on quantitative data of the various emergy flows that are transformed within each tilapia cage farming system analyzed. Thus, the evaluated indices were adapted from Odum (1996) and Brown and Ulgiati (2004) (Table 2).

Transformity $(\operatorname{Tr})$ is the ratio between the emergy required to make a product and the energy of it; its unity is the sej/J (solar emergy joule). The transformity evaluates only productivity efficiency and does not consider the source of the resource used (e.g., renewable, non-renewable, economic). Because of this, this index should not be the only way to evaluate the ecosystem performance (Zhang et al., 2011). In this context, it is necessary to evaluate the

Table 2

Emergy indices used in the evaluation.

\begin{tabular}{lll}
\hline Indices & & Formula $^{\mathrm{a}}$ \\
\hline $\mathrm{Tr}$ & Transformity & $\mathrm{Tr}=$ Emergy/Energy \\
$\% \mathrm{R}$ & Renewability & $100 \times(\mathrm{R} / \mathrm{Y})$ \\
$\mathrm{EYR}$ & Emergy yield ratio & $\mathrm{EYR}=\mathrm{Y} / \mathrm{F}$ \\
$\mathrm{EIR}$ & Emergy investment ratio & $\mathrm{EIR}=\mathrm{F} /(\mathrm{R}+\mathrm{N})$ \\
ELR & Environmental loading ratio & $\mathrm{ELR}=(\mathrm{F}+\mathrm{N}) / \mathrm{R}$ \\
$\mathrm{EER}$ & Emergy exchange ratio & $\mathrm{EER}=\mathrm{Y} /[(\$) \times(\mathrm{sej} / \$)]$ \\
ESI & Emergy sustainability index & $\mathrm{ESI}=\mathrm{EYR} / \mathrm{ELR}$ \\
\hline
\end{tabular}

${ }^{a} \mathrm{R}$ : renewable resources from nature; $\mathrm{N}$ : non-renewable resources; F: resources from economy; Y: productive yield. other indices individually and together, since each one has a different approach to analyze the efficiency of the evaluated system. Renewability (\%R) is the ratio of the renewable resources divided by the total emergy of the system. The emergy yield ratio (EYR) is the ratio of the emergy of the product divided by the emergy of the resources from economy used. It provides a measure of how much a production process will contribute to the economy, balancing costs and benefits. The emergy investment ratio (EIR) is the ratio of emergy of resources from economy divided by the emergy of renewable resources from nature. This index shows whether a process efficiently utilizes the emergy that is invested in comparison to other alternatives. The environmental loading ratio (ELR) is the ratio of non-renewable energy, including resources from economy, to renewable emergy. The emergy exchange ratio (EER) is the ratio of the exchange rate to a financial transaction, considering the relation between the emergy contained in the product and the emergy contained in the money received by its sale. These indices express the exchange ratio of one or more exchange partnerships and is a measure of the relative advantage that is established between the exchange partners. The emergy sustainability index (ESI) is the ratio between the emergy yield ratio (EYR) and the emergy loading ratio (ELR). This is an index that shows the measure of the contribution of a process to the economy per unit of environmental impact that it generates.

\section{Results}

The production model of $80 \mathrm{~kg} / \mathrm{m}^{3}$ under traditional management without substrate (TRAD) used $3.80 \mathrm{E}+15 \mathrm{sej} /$ year to produce $411.79 \mathrm{~kg}$ of Nile tilapia/cage (Table 3), while the models with food restriction and addition of substrates for periphyton, with 80 and $40 \mathrm{~kg} / \mathrm{m}^{3}$ (TDS and LDS) required $2.45 \mathrm{E}+15 \mathrm{sej} / \mathrm{year}$ (Table 4) and $1.49 \mathrm{E}+15$ sej/year (Table 5) to produce $417.84 \mathrm{~kg} /$ cage and $214.54 \mathrm{~kg} /$ cage, respectively. The resources from economy had the highest proportion of the emergy inputs in all evaluated managements, representing $87 \%$ in the TRAD, $78 \%$ in the TDS, and $65 \%$ in the LDS. On the other hand, the participation of renewable 
Table 3

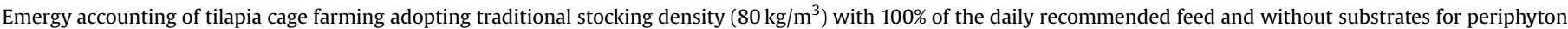
(TRAD).

\begin{tabular}{|c|c|c|c|c|c|c|}
\hline Note & Item & Unit & Annual flow ${ }^{\mathrm{a}}$ & UEV (seJ/unit) & Emergy (sej/year) & Reference \\
\hline \multicolumn{7}{|c|}{ Renewable resources $(R)$} \\
\hline 1 & Sun & $\mathrm{J}$ & $1.43 E+13$ & $1.00 \mathrm{E}+00$ & $1.43 \mathrm{E}+13$ & Odum, 2000 \\
\hline 2 & Rain & $\mathrm{J}$ & $2.00 \mathrm{E}+10$ & $2.36 \mathrm{E}+04$ & $4.71 \mathrm{E}+14$ & Odum, 2000 \\
\hline 3 & Wind & $\mathrm{J}$ & $1.32 \mathrm{E}+09$ & $1.86 \mathrm{E}+03$ & $2.46 \mathrm{E}+12$ & Odum, 2000 \\
\hline Total & & & & & $4.87 \mathrm{E}+14$ & \\
\hline \multicolumn{7}{|c|}{ Resources from economy $(F)$} \\
\hline 4 & Juveniles & $\mathrm{J}$ & $9.04 \mathrm{E}+08$ & $7.15 \mathrm{E}+05$ & $6.46 \mathrm{E}+14$ & Brown and Bardi (2001) \\
\hline 5 & Electricity & $\mathrm{J}$ & $3.58 \mathrm{E}+07$ & $8.51 \mathrm{E}+04$ & $3.05 \mathrm{E}+12$ & Häyhä et al. (2011) \\
\hline 6 & Gasoline & $\mathrm{J}$ & $4.61 \mathrm{E}+07$ & $6.77 \mathrm{E}+04$ & $3.12 \mathrm{E}+12$ & Brown and Bardi (2001) \\
\hline 7 & Feed & $\mathrm{J}$ & $2.56 \mathrm{E}+10$ & $9.96 \mathrm{E}+04$ & $2.55 \mathrm{E}+15$ & Brown and Bardi (2001) \\
\hline 8 & Infrastructure and equipment & $\$$ & $3.27 \mathrm{E}+01$ & $3.44 \mathrm{E}+12$ & $1.12 \mathrm{E}+14$ & Pereira et al. (2013) \\
\hline 9 & Human labor & $\mathrm{J}$ & $9.28 \mathrm{E}+04$ & $3.27 \mathrm{E}+06$ & $3.03 E+11$ & Oliveira et al. (2018) \\
\hline Total & & & & & $3.32 \mathrm{E}+15$ & \\
\hline \multicolumn{7}{|c|}{ Production yield $(Y)$} \\
\hline 10 & Fish & $\mathrm{J}$ & $1.35 \mathrm{E}+10$ & & $3.80 \mathrm{E}+15$ & \\
\hline
\end{tabular}

${ }^{a}$ Values per cage with area for renewable resources of $3.20 \mathrm{E}+03 \mathrm{~m}^{2}$.

Table 4

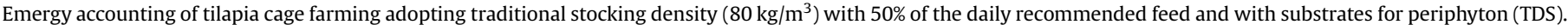

\begin{tabular}{|c|c|c|c|c|c|c|}
\hline Note & Item & Unit & Annual flow ${ }^{a}$ & UEV (seJ/unit) & Emergy (sej/year) & Reference \\
\hline 1 & Sun & $\mathrm{J}$ & $1.43 \mathrm{E}+13$ & $1.00 \mathrm{E}+00$ & $1.43 \mathrm{E}+13$ & Odum, 2000 \\
\hline 2 & Rain & $\mathrm{J}$ & $2.00 \mathrm{E}+10$ & $2.36 \mathrm{E}+04$ & $4.71 \mathrm{E}+14$ & Odum, 2000 \\
\hline 3 & Wind & $\mathrm{J}$ & $1.32 \mathrm{E}+09$ & $1.86 \mathrm{E}+03$ & $2.46 \mathrm{E}+12$ & Odum, 2000 \\
\hline 4 & Periphyton & $\mathrm{J}$ & $6.31 \mathrm{E}+09$ & $2.71 \mathrm{E}+03$ & $1.71 \mathrm{E}+13$ & Brown et al. (2006) \\
\hline 5 & Bamboo & $\mathrm{kg}$ & $5.20 \mathrm{E}+01$ & $4.90 \mathrm{E}+11$ & $2.55 \mathrm{E}+13$ & Liu (2008) \\
\hline Total & & & & & $5.30 \mathrm{E}+14$ & \\
\hline \multicolumn{7}{|c|}{ Resources from economy $(F)$} \\
\hline 6 & Juveniles & $\mathrm{J}$ & $7.48 \mathrm{E}+08$ & $7.15 \mathrm{E}+05$ & $5.35 \mathrm{E}+14$ & Brown and Bardi (2001) \\
\hline 7 & Electricity & $\mathrm{J}$ & $8.53 \mathrm{E}+06$ & $8.51 \mathrm{E}+04$ & $7.26 \mathrm{E}+11$ & Häyhä et al. (2011) \\
\hline 8 & Gasoline & $\mathrm{J}$ & $3.82 \mathrm{E}+07$ & $6.77 \mathrm{E}+04$ & $2.58 \mathrm{E}+12$ & Brown and Bardi (2001) \\
\hline 9 & Feed & $\mathrm{J}$ & $1.28 \mathrm{E}+10$ & $9.96 \mathrm{E}+04$ & $1.27 \mathrm{E}+15$ & Brown and Bardi (2001) \\
\hline 10 & Infrastructure and equipment & $\$$ & $3.27 \mathrm{E}+01$ & $3.44 \mathrm{E}+12$ & $1.12 \mathrm{E}+14$ & Pereira et al. (2013) \\
\hline 11 & Human labor & $\mathrm{J}$ & $7.00 \mathrm{E}+04$ & $3.27 \mathrm{E}+06$ & $2.29 \mathrm{E}+11$ & Oliveira et al. (2018) \\
\hline Total & & & & & $1.92 \mathrm{E}+15$ & \\
\hline \multicolumn{7}{|c|}{ Production yield $(Y)$} \\
\hline 12 & Fish & $\mathrm{J}$ & $1.60 \mathrm{E}+10$ & & $2.45 \mathrm{E}+15$ & \\
\hline
\end{tabular}

${ }^{a}$ Values per cage with area for renewable resources of $3.20 \mathrm{E}+03 \mathrm{~m}^{2}$.

Table 5

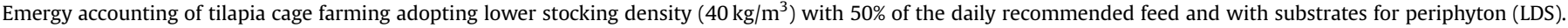

\begin{tabular}{|c|c|c|c|c|c|c|}
\hline Note & Item & Unit & Annual flow* & UEV (seJ/unit) & Emergy (sej/year) & Reference \\
\hline \multicolumn{7}{|c|}{ Renewable resources $(R)$} \\
\hline 1 & Sun & $\mathrm{J}$ & $1.43 \mathrm{E}+13$ & $1.00 \mathrm{E}+00$ & $1.43 \mathrm{E}+13$ & Odum, 2000 \\
\hline 2 & Rain & $\mathrm{J}$ & $2.00 \mathrm{E}+10$ & $2.36 \mathrm{E}+04$ & $4.71 \mathrm{E}+14$ & Odum, 2000 \\
\hline 3 & Wind & $\mathrm{J}$ & $1.32 \mathrm{E}+09$ & $1.86 \mathrm{E}+03$ & $2.46 \mathrm{E}+12$ & Odum, 2000 \\
\hline 4 & Periphyton & $\mathrm{J}$ & $3.68 \mathrm{E}+09$ & $2.71 \mathrm{E}+03$ & $9.95 \mathrm{E}+12$ & Brown et al. (2006) \\
\hline 5 & Bamboo & $\mathrm{kg}$ & $5.20 \mathrm{E}+01$ & $4.90 \mathrm{E}+11$ & $2.55 \mathrm{E}+13$ & Liu $(2008)$ \\
\hline Total & & & & & $5.26 \mathrm{E}+14$ & \\
\hline \multicolumn{7}{|c|}{ Resources from economy $(F)$} \\
\hline 6 & Juveniles & $\mathrm{J}$ & $3.74 \mathrm{E}+08$ & $7.15 \mathrm{E}+05$ & $2.68 \mathrm{E}+14$ & Brown and Bardi (2001) \\
\hline 7 & Electricity & $\mathrm{J}$ & $2.88 \mathrm{E}+07$ & $8.51 \mathrm{E}+04$ & $2.45 \mathrm{E}+12$ & Häyhä et al. (2011) \\
\hline 8 & Gasoline & $\mathrm{J}$ & $3.71 \mathrm{E}+07$ & $6.77 \mathrm{E}+04$ & $2.51 \mathrm{E}+12$ & Brown and Bardi (2001) \\
\hline 9 & Feed & $\mathrm{J}$ & $5.80 \mathrm{E}+09$ & $9.96 \mathrm{E}+04$ & $5.77 \mathrm{E}+14$ & Brown and Bardi (2001) \\
\hline 10 & Infrastructure and equipment & $\$$ & $3.27 \mathrm{E}+01$ & $3.44 \mathrm{E}+12$ & $1.12 \mathrm{E}+14$ & Pereira et al. (2013) \\
\hline 11 & Human labor & $\mathrm{J}$ & $6.04 \mathrm{E}+04$ & $3.27 \mathrm{E}+06$ & $1.97 \mathrm{E}+11$ & Oliveira et al. (2018) \\
\hline Total & & & & & $9.62 \mathrm{E}+14$ & \\
\hline \multicolumn{7}{|c|}{ Production yield $(Y)$} \\
\hline 12 & Fish & $\mathrm{J}$ & $3.92 \mathrm{E}+09$ & & $1.49 \mathrm{E}+15$ & \\
\hline
\end{tabular}

* Values per cage with area for renewable resources of $3.20 \mathrm{E}+03 \mathrm{~m}^{2}$.

resources from nature was higher in LDS treatment with 35\%, compared to $22 \%$ in TDS and 13\% in TRAD. In the systems with substrate for periphyton, bamboo and periphyton represented approximately $2.30 \%$ of total emergy in both systems (TDS and LDS). The contribution of non-renewable resources from nature was not considered in the three evaluated systems.

In all production managements, the feed was the item with the highest emergy expenditure (Fig. 2). In the two treatments that used a density of $80 \mathrm{~kg} / \mathrm{m}^{3}$ (TRAD and TDS), juveniles were the second most representative item with an average of $19.55 \%$. 


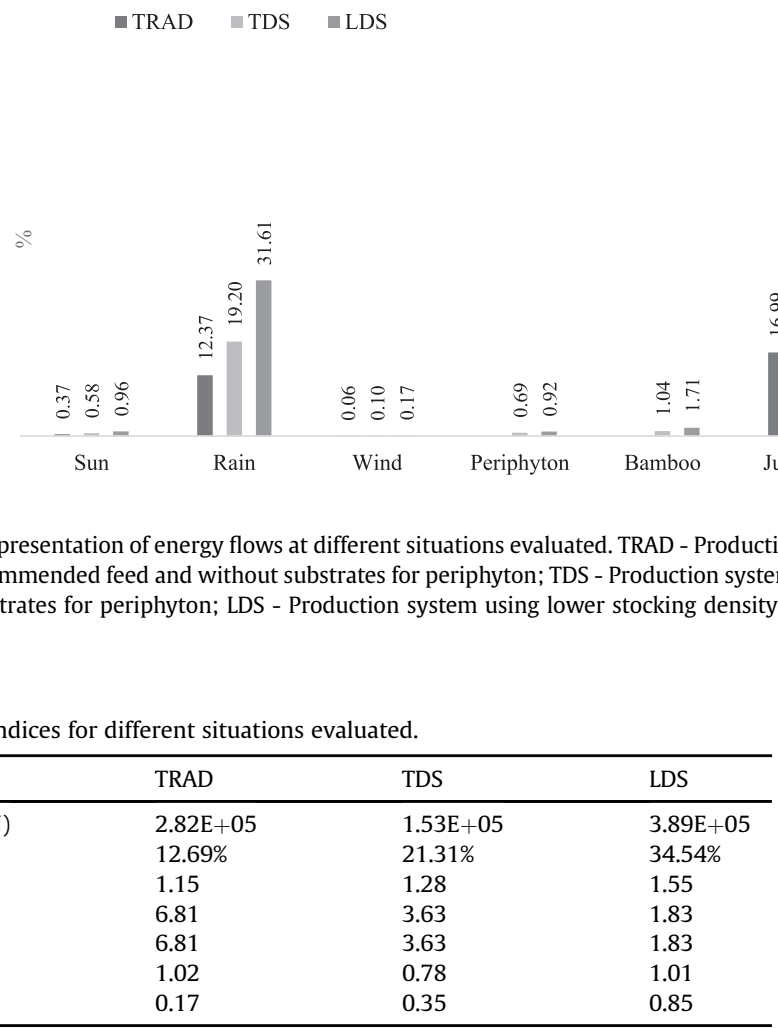

Meanwhile, in the management that used a density of $40 \mathrm{~kg} / \mathrm{m}^{3}$ (LDS), the second most representative item was rain, a local renewable resource. Although they have different representability, the amount of renewable resources that entered in the processes were the same in the two strategies, considering that the cages were the same and were in the same place at the same time.

The transformity of TRAD was almost twice as high as the TDS while LDS presented higher transformity than the other two managements evaluated. The EIR and ELR indices were higher in TRAD than LDS (3.7 times) and TDS (1.9 times). The EER of TDS was 23\% lower than TRAD and LDS. The EYR and ESI of LDS was higher than TDS (1.3 and 2.4 times respectively) and TRAD (1.2 and 5.0 times respectively) (Table 6).

\section{Discussion}

In all production managements, the resources from economy were the main items that contributed to the emergy flow (Fig. 2). As verified by Garcia et al. (2014), this trend shows that tilapia cage farming is dependent on the economic inputs, and the feed is mainly responsible for this because it has high transformity value and, in intensive aquaculture, is used in large amounts (Ayroza et al., 2011; Garcia et al., 2013, 2014). The feed impact on aquaculture sustainability is poorly documented by emergy assessment. Some results by Life Cycle Analysis (LCA), another method of measuring sustainability, also show that feed is the main factor that negatively impacts aquaculture production (Wilfart et al., 2013; Yacout et al., 2016).

The decrease in stocking density and feed amount, when feed restriction and the use of periphyton as complementary food were applied reduced the dependence of resources from economy. Moreover, periphyton and lower stocking density (TDS and LDS) managements used less emergy to produce tilapia in a cage in the one-year period compared to the traditional without substrate for periphyton management (TRAD) (Fig. 2). This can be explained by the reduction in the amount of resources from economy with high transformity (such as feed, gasoline, and juveniles) and the inclusion of renewable items with less transformity (such as periphyton, which performs the same function as reduced feed).

Considering that transformity is defined by the inverse relation of ecosystem efficiency, TDS management presented the best result due to the lower value of transformity, which indicates a better process performance to generate a service or product (Odum, 1996; Brown and Ulgiati, 2004) since this management can produce more tilapia by less emergy invested compared to TRAD and LDS. Zhang et al. (2011) discuss this same trend in the evaluation of different aquaculture systems. These authors verified that carp cage farming using natural food achieved better ecosystem efficiency in comparison to the other systems that used commercial feed. In LDS, the lower production of tilapia $(\mathrm{kg} / \mathrm{year})$ was responsible for its lower global productivity due to the low use of invested energy. Garcia et al. (2014) evaluated different densities and areas for dilution of the environmental load in tilapia cage farming and observed that a lower density negatively affects the efficiency of the system. This trend is evidenced in other studies that evaluated the sustainability of extensive aquaculture systems (Odum, 2001; Bastianoni, 2002; Cavalett et al., 2006; Vassallo et al., 2007; Cheng et al., 2017).

The renewability (\%R) shows that the systems using periphyton (TDS and LDS) are more renewable and less dependent on the resources from economy than the traditional cultivation system (TRAD). This can be explained by the reduction in the use of commercial feed in these treatments, combined with insertion of bamboo substrates for periphyton growth as renewable resources in the system. The high renewability of LDS is a consequence of the combination of these two factors with the use of low density, which reduced the use of resources from economy. This trend also was observed by Garcia et al. (2014) when performing the emergy accounting of different densities in tilapia cage farming.

In relation to EYR, the values of the three managements can be considered low, reflecting the low contribution of renewable resources revealed in the analysis of the emergy flows. The value of EYR close to 1 in TRAD indicates that the systems were inefficient to incorporate emergy from local renewable resources in the production process (Brown and Ulgiati, 2004). This result also shows that TRAD management make available to society the same amount of emergy consumed in the tilapia production process and did not aggregate emergy to the final product, this means that the emergy yield is close to the same amount of purchased emergy (Li et al., 2011; Cheng et al., 2017). Although the use of periphyton and density reduction (TDS and LDS) increased EYR, values remained 
low and close to 1 , as in other intensive fish production systems evaluated by Cavalett et al. (2006), Zhang et al. (2011), and Vassallo et al. (2007).

The EIR and ELR showed the same performance in all evaluated managements (Table 6); this result is related to the non-inclusion of non-renewable nature items in the emergy accounting (Odum, 2001). The EIR allows identification of if, in a production process, the use of resources from economy will be equivalent to the natural resources. Quantitatively, this means that lower EIR values indicate a better efficiency in the use of renewable resources from nature, where energy is constantly renewed and can supply the production system continuously (Odum, 1996; Brown and Ulgiati, 2004). In this sense, LDS is shown to have more emergy balance and more effective system with better use of renewable emergy sources compared to the other treatments. However, in all evaluated managements the input of resources from the economy is much larger than the input of renewable resources, characteristics of the production in open or intensive systems which use large amounts of feed or high feed conversion. Similar results presented by Odum (2001), Cavalett et al. (2006), and Cheng et al. (2017) suggest that this is probably a standard of aquaculture practice.

On the other hand, the ELR indicates the pressure that the process has on the environment and can be considered a way to measure the environmental stress due to a productive activity. In numbers, ELR values equal to or lower than 2 indicate low environmental impacts, between 3 and 10 indicate moderate environmental impacts, and equal to or greater than 10 indicate high environmental impacts (Brown and Ulgiati, 2004). In this way, the results obtained in the present study (Table 6) show that tilapia cage farming, using periphyton or not, is an activity with moderate impact. Other authors also have classified their aquaculture systems as an activity with moderate impact, independent of the intensification level (Odum, 2001; Bastianoni, 2002; Cavalett et al., 2006; Vassallo et al., 2007; Zhang et al., 2011; Cheng et al., 2017). However, the values of the LDS demonstrate that the decrease in stocking density is an efficient alternative to decrease the environmental load generated by the activity. In this management, even with the high input of resources from economy in a small area $\left(4 \mathrm{~m}^{2}\right)$, the dilution area established by the legislation $\left(3200 \mathrm{~m}^{2}\right)$ was sufficient to dilute the impacts caused by tilapia culture in this analyzed situation.

Among the evaluated indices, the EER and ESI give more emphasis to the impact of production on the economy. The EER measures the emergy exchanged in a trade or purchase (what is received to what is given). The ratio is always expressed relative to one or the other trading partner and is a measure of the relative trade advantage of one partner over the other (Brown and Ulgiati, 2004). In a fair trade, the value of EER is equal to 1, indicating the consumer offers emergy in the form of money and receives the same quantity of emergy in the commodity (Zhang et al., 2011). However, in the market as it is practiced today, it is not equitable, since products have much more emergy than what is economically valued (Zhang et al., 2011). The EER aims to correct this imbalance by using the emergy as money, adding the ecosystem value of resources to the value of the product and excluding the strictly economic character, a situation that considers only the value of human labor and the goods of the economy (Odum, 1996; Cavalett et al., 2006).

The EER values of TRAD and LDS indicate that the production managements analyzed provide almost the same emergy to the consumer than they receive in exchange for their sales. EER values higher than 1 is a trend of intensive productions that use few resources from nature and has high dependence on the contributions from economy to maintain it (Odum, 2001; Zhang et al., 2011). Results found by Cavalett et al. (2006) showed that the monoculture of fish offers more emergy to the economy than the integrated system. This same pattern was reported by Odum (2001) in which the sales value of salmon grown in the United States should be double the current. On the other hand, the EER of the TDS was lower than 1, showing that if renewable resources started being valued, tilapia cultivated in this way may have its sales value reduced by $22 \%$. Thus, in the first instance the use of periphyton as a complementary food will make production cheaper, favor the producer and stimulate the development of this type of system. In the medium term, this cost reduction will benefit the consumer due to the consequent decrease of the final price.

The ESI is an index that also considers the economy, measuring how much the production process contributes to the economy in relation to the environmental impact generated-that is, indicates the sustainability of the process (Brown \& Ulgiati, 1997, 2004; Zhang et al., 2011). Values lower than 1, as found in all the management analyzed in the present study, indicate that tilapia cage farming provides a very low emergy return in relation to the high environmental load they generate. This also seems to be a standard in intensive aquaculture systems, since Odum (2001), Vassallo et al. (2007), and Zhang et al. (2011) recorded this same trend when they used high intensification levels.

In this way, the commercial feed is the main item responsible for making tilapia cage farming in Brazil an activity highly dependent on resources from economy. This large economic participation makes this system very susceptible to market variations, a factor that may make production unviable in possible price variations and the supply of inputs, for example. Studies such as Garcia et al. (2016) and Zhang et al. (2011), which aim to use alternative food to commercial feed, should be encouraged as one of the ways to reduce dependence on the economy and increase the representativeness of nature's renewable resources in aquaculture production. It was verified that management with decrease in density does not seem to be an efficient production strategy (due to the high transformity) but provides the best sustainable performance. According to the emergy analysis, the reduction in artificial feed utilization, as a result of the adoption of substrates with periphyton, should become a practice to be considered in aquaculture because it may possibly facilitate sustainability in the production system, mainly in the production of tilapia. This is because the tilapia shows opportunistic omnivore feeding behavior and have morphological adaptations that allow it to feed on phytoplankton and periphyton (Sanderson et al., 1996). The consumption of periphyton by tilapia is a fact that was already elucidated and reported, this fish consumes quantities up to 25 times larger of periphyton than phytoplankton. This occurs because to graze a two-dimensional layer of periphyton is mechanically more efficient than filtering planktonic algae in a three-dimensional environment. This behavior can positively affect the growth, development, survival of the fish produced and increase the yield of the systems (Dempster et al., 1993).

The results of this study indicate that the adoption of practices and management that reduce the dependence on resources from economy and increase the use of renewable resources help to make aquaculture a resilient and more economically fair activity with lower negative environmental impacts. Moreover, emphasis is placed on the importance of using methods that can point out the problems within a production in order to indicate alternative practices aimed at sustainable aquaculture. This information should also be used in the elaboration of public policies that regulate the use of non-renewable resources and the intensification of the aquaculture systems implanted in public reservoirs. The emergy method also showed that systems and management based on the premise of increasing aquaculture sustainability must be submitted to these analyses to verify its real development, environmental impact, and ecosystem efficiency. 


\section{Acknowledgements}

This study has been funded by the São Paulo Research Foundation (2013/18721-6 and 2016/07696-9).

\section{Appendix A. Supplementary data}

Supplementary data related to this article can be found at https://doi.org/10.1016/j.jclepro.2018.08.124.

\section{References}

Ayroza, L.M. da S., Romagosa, E., Ayroza, D.M.M. de R., Filho, J.D.S., Salles, F.A., 2011. Custos e rentabilidade da produção de juvenis de tilápia-do-nilo em tanquesrede utilizando-se diferentes densidades de estocagem. Rev. Bras. Zootec. 40 231-239. https://doi.org/10.1590/S1516-35982011000200001.

Azim, M.E., Asaeda, T., 2005. Periphyton structure, diversity and colonization. In: Azim, M.E., Verdegem, M.C.J., Van Dan, A.A., Beveridge, M.C.M. (Eds.), Periphyton: Ecology, Exploitation and Management. CABI Publishing, Cambridge, pp. 15-33.

Bastianoni, S., 2002. Use of thermodynamic orientors to assess the efficiency of ecosystems: a case study in the lagoon of Venice. Sci. World J. 2, 255-260. https://doi.org/10.1100/tsw.2002.88.

Boyd, C.E., 2003. Guidelines for aquaculture effluent management at the farm-level. Aquaculture 226, 101-112. https://doi.org/10.1016/S0044-8486(03)00471-X.

BRASIL, 2004. Instrução Normativa Interministerial n 06 de 31 de maio de 2004. Available from: http://www.planejamento.gov.br/secretarias/upload/Legislacao /InstrucaoNormativa/040531INinter06.pdf (accessed on october 2017).

Bronnmann, J., Asche, F., 2017. Sustainable seafood from aquaculture and wild fisheries: insights from a discrete choice experiment in Germany. Ecol. Econ. 142, 113-119. https://doi.org/10.1016/j.ecolecon.2017.06.005.

Brown, M.T., Bardi, E., 2001. Emergy of ecosystems folio \#3. A compend. Data Emergy Comput. 94

Brown, M.T., Campbell, D.E., De Vilbiss, C., Ulgiati, S., 2016. The geobiosphere emergy baseline: a synthesis. Ecol. Model. 339, 92-95. https://doi.org/10.1016/ j.ecolmodel.2016.03.018.

Brown, M.T., Cohen, M.J., Bardi, E., Ingwersen, W.W., 2006. Species diversity in the Florida Everglades, USA: a systems approach to calculating biodiversity. Aquat Sci. 68, 254-277. https://doi.org/10.1007/s00027-006-0854-1.

Brown, M.T., Ulgiati, S., 1997. Emergy-based indices and ratios to evaluate sustainability: monitoring economies and technology toward environmentally sound innovation. Ecol. Eng. 9, 51-69. https://doi.org/10.1016/S0925-8574(97) 00033-5.

Brown, M.T., Ulgiati, S., 2004. Emergy analysis and environmental accounting. Encycl. Energy. https://doi.org/10.1016/B0-12-176480-X/00242-4.

Brown, M.T., Ulgiati, S., 2016. Assessing the global environmental sources driving the geobiosphere: a revised emergy baseline. Ecol. Model. 339, 126-132. https://doi.org/10.1016/j.ecolmodel.2016.03.017.

Campbell, D.E., 2016. Emergy baseline for the Earth: a historical review of the science and a new calculation. Ecol. Model. 339, 96-125. https://doi.org/10.1016/ j.ecolmodel.2015.12.010.

Campbell, D.E., Brandt-Williams, S.L., Cai, T., 2005. Current technical problems in emergy analysis. In: Proc. From Third Bienn. Emergy Conf..

Cavalett, O., Queiroz, J.F. De, Ortega, E., 2006. Emergy assessment of integrated production systems of grains, pig and fish in small farms in the South Brazil. Ecol. Model. 193, 205-224. https://doi.org/10.1016/j.ecolmodel.2005.07.023.

Cheng, H., Chen, C., Wu, S., Mirza, Z.A., Liu, Z., 2017. Emergy evaluation of cropping, poultry rearing, and fish raising systems in the drawdown zone of Three Gorges Reservoir of China. J. Clean. Prod. 144, 559-571. https://doi.org/10.1016/ j.jclepro.2016.12.053.

Copeland, H.E., Tessman, S.A., Girvetz, E.H., Roberts, L., Enquist, C., Orabona, A., Patla, S., Kiesecker, J., 2010. A geospatial assessment on the distribution, condition, and vulnerability of Wyoming's wetlands. Ecol. Indic. 10, 869-879. https://doi.org/10.1016/j.ecolind.2010.01.011.

Dempster, P., Beveridge, M., Baird, D., 1993. Herbivory in the tilapia Oreochromis niloticus: a comparison of feeding rates on phytoplankton and periphyton. J. Fish. Biol. https://doi.org/10.1006/jfbi.1993.1140.

FAO, 2016. The State of World Fisheries and Aquaculture. FAO, Rome, p. 200.

Garcia, F., Romera, D.M., Gozi, K.S., Onaka, E.M., Fonseca, F.S., Schalch, S.H.C., Candeira, P.G., Guerra, L.O.M., Carmo, F.J., Carneiro, D.J., Inez, M., Martins, E.G., Célia, M., 2013. Stocking density of Nile tilapia in cages placed in a hydroelectric reservoir. Aquaculture 410-411, 51-56. https://doi.org/10.1016/j.aquaculture. 2013.06.010.
Garcia, F., Kimpara, J.M., Valenti, W.C., Ambrosio, L.A., 2014. Emergy assessment of tilapia cage farming in a hydroelectric reservoir. Ecol. Eng. 68, 72-79. https:// doi.org/10.1016/j.ecoleng.2014.03.076.

Garcia, F., Romera, D.M., Sousa, N.S., Paiva-Ramos, I., Onaka, E.M., 2016. The potential of periphyton-based cage culture of Nile tilapia in a Brazilian reservoir Aquaculture 464, 229-235. https://doi.org/10.1016/j.aquaculture.2016.06.031.

Garcia, F., Sabbag, O.J., Kimpara, J.M., Romera, D.M., Sousa, N.S., Onaka, E.M., Ramos, I.P., 2017. Periphyton-based cage culture of Nile tilapia: an interesting model for small-scale farming. Aquaculture 479, 838-844. https://doi.org/ 10.1016/j.aquaculture.2017.07.024.

Häyhä, T., Franzese, P.P., Ulgiati, S., 2011. Economic and environmental performance of electricity production in Finland: a multicriteria assessment framework. Ecol. Model. 223, 81-90. https://doi.org/10.1016/j.ecolmodel.2011.10.013.

IBGE, 2015. Produção pecuária 2015. Produção Pecuária. Munic. 43, 1-49.

Li, L., Lu, H., Ren, H., Kang, W., Chen, F., 2011. Emergy evaluations of three aquaculture systems on wetlands surrounding the Pearl River Estuary, China. Ecol. Indic. 11, 526-534. https://doi.org/10.1016/j.ecolind.2010.07.008.

Liu, Y., 2008. Emergy-based Evaluation of Industrial Model Selection in Natura Protected Area- a Case Study of Wuyishan Mountain. Beijing Normal University Beijing.

Lomas, P.L., Alvarez, S., Rodriguez, M., Montes, C., 2008. Environmental accounting as a management tool in the Mediterranean context: the Spanish economy during the last 20 years. J. Environ. Manag. 88, 326-347. https://doi.org/ 10.1016/j.jenvman.2007.03.009.

Maciel, P.O., Garcia, F., Chagas, E.C., Fujimoto, R.Y., Tavares-Dias, M., 2017. Trichodinidae in commercial fish in South America. Rev. Fish Biol. Fish. https://doi.org $10.1007 / \mathrm{s} 11160-017-9490-1$.

Mallasen, M., Carmo, C.F., Tucci, A., Barros, H.P., Rojas, N.E.T., Fonseca, F.S. Yamashita, E.Y., 2012. Qualidade da água em sistema de piscicultura em tanques-rede no reservatório de Ilha Solteira, SP. Bol. Inst. Pesca 38, 15-30.

Marengoni, N.G., 2006. Produção de tilápia do nilo Oreochromis niloticus (Linhagem Chitralada), Cultivada Em Tanques-Rede, Sob Diferentes Densidades De Estocagem. Arch. Zootec. 55, 127-138.

Monteiro, S.H., Francisco, J.G., Andrade, G.C.R.M., Botelho, R.G., Figueiredo, L.A. Tornisielo, V.L., 2016. Study of spatial and temporal distribution of antimicrobia in water and sediments from caging fish farms by on-line SPE-LC-MS/MS J. Environ. Sci. Heal. Part B 51, 634-643. https://doi.org/10.1080/03601234. 2016.1181917.

Odum, H.T., 1996. Environmental Accounting. Emergy and Environmental Decision Making. John Wiley \& Sons, Inc.

Odum, H.T. 2000. Handbook of Emergy Evaluation. A Compendium of Data for Emergy Computation. Folio \#2 Emergy Global Processes. Center of Environmental Policy, University of Florida, Gainesville.

Odum, H.T., 2001. Emergy Evaluation of Salmon Pen Culture. University of Florida Press.

Oliveira, J.H., Giannetti, B.F., Agostinho, F., Almeida, C.M.V.B., 2018. Decision making under the environmental perspective: choosing between traditional and distance teaching courses. J. Clean. Prod. 172, 4303-4313. https://doi.org/10.1016/j. jclepro.2017.06.189.

Pereira, L., Zucaro, A., Ortega, E., Ulgiati, S., 2013. Wealth, trade and the environment: carrying capacity, economic performance and wellbeing in Brazil and Italy. J. Environ. Acc. Manag. 1, 159-188.

Pulselli, R.M., 2010. Integrating emergy evaluation and geographic information systems for monitoring resource use in the Abruzzo region (Italy). J. Environ. Manag. 91, 2349-2357. https://doi.org/10.1016/j.jenvman.2010.06.021.

SÃO PAULO, 2016. Decreto $n^{\circ} 62.243$, de 01 de novembro de 2016. Available from: http://www.al.sp.gov.br/repositorio/legislacao/decreto/2016/decreto-62243-01. 11.2016.html (accessed on october 2017).

Sanderson, S.L., Stebar, M.C., Ackerman, K.L., Jones, S.H., Batjakas, I.E., Kaufman, L. 1996. Mucus entrapment of particles by suspension-feeding tilapia (Pisces: Cichlidae). J. Exp. Biol. 199, 1743-1756.

Valenti, W.C., Kimpara, J.M., Preto, B.D.L., 2011. Measuring aquaculture sustainability. World Aquacult. 42, 26-30.

Vassallo, P., Bastianoni, S., Beiso, I., Ridolfi, R., Fabiano, M., 2007. Emergy analysis for the environmental sustainability of an inshore fish farming system. Ecol. Indic. 7, 290-298. https://doi.org/10.1016/j.ecolind.2006.02.003.

Wilfart, A., Prudhomme, J., Blancheton, J., Aubin, J., 2013. LCA and emergy accounting of aquaculture systems: towards ecological intensification. J. Environ. Manag. 121, 96-109. https://doi.org/10.1016/j.jenvman.2013.01.031.

Yacout, D.M.M., Soliman, N.F., Yacout, M.M., 2016. Comparative life cycle assessment (LCA) of Tilapia in two production systems: semi-intensive and intensive. Int. J. Life Cycle Assess. 21, 806-819. https://doi.org/10.1007/s11367-016-1061-5.

Zhang, L.X., Ulgiati, S., Yang, Z.F., Chen, B., 2011. Emergy evaluation and economic analysis of three wetland fish farming systems in Nansi Lake area, China. J. Environ. Manag. 92, 683-694. https://doi.org/10.1016/j.jenvman.2010.10.005. 